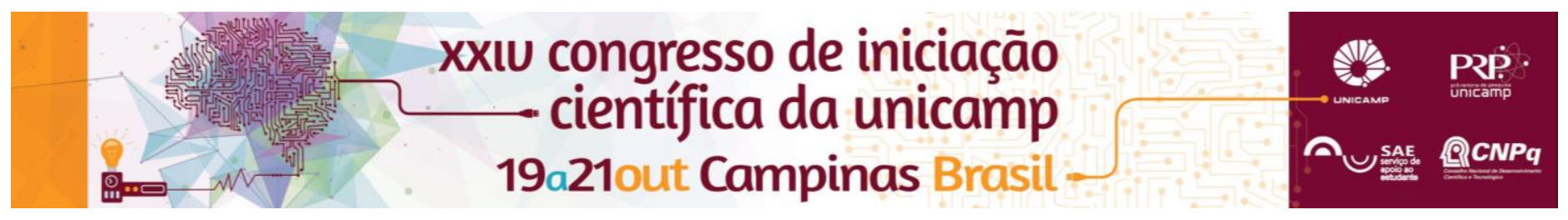

\title{
Um best seller real: Uma análise literária do primeiro volume da série "O Diário da Princesa".
}

\author{
Clarissa Resende Rosa*
}

\begin{abstract}
Resumo
Esta pesquisa tem como proposta realizar uma análise literária do best seller da escritora estadunidense Meg Cabot, "O Diário da Princesa". A obra é sem dúvidas uma campeã de vendas, atingiu o número de 5 milhões de exemplares vendidos e foi publicada em 38 países. Tais êxitos conferem ao livro o rótulo de best seller, expressão que envolve questões relacionadas aos aspectos editoriais quantitativos e ao mesmo tempo aspectos qualitativos e juízos de valor, os quais pressupõem a divisão entre uma alta literatura e uma baixa literatura. Dessa forma, o que se pretende nesse projeto é um estudo que se desvincule de uma defesa da alta literatura, analisando a construção do best selller "O Diário da Princesa" à luz do conceito de realismo formal proposto pelo crítico lan Watt.
\end{abstract}

\section{Palavras-chave:}

Teoria Literária, Indústria Cultural,Best Seller.

\section{Introdução}

Este projeto tem como objetivo realizar uma análise literária do romance da escritora estadunidense Meg Cabot, "O Diário da Princesa", à luz do realismo formal proposto pelo crítico lan Watt. Essa narrativa, por ter alcançando altas tiragens, chegando a atingir o número de 5 milhões de exemplares vendidos em seu país de origem e 800 mil no Brasil, carrega o rótulo de best seller. A determinação terminológica do best seller carrega em si aspectos qualitativos e juízos de valor, espelhados em opiniões de críticos e teóricos da literatura, que sintetizam suas classificações baseadas na linguagem, na originalidade da narrativa e na consistência do conteúdo, o que implica em uma noção de campo literário dividido e polarizado, no qual de um lado temos a alta literatura, com suas normas e hierarquias e, em oposição a ela, uma baixa literatura, que se distancia do padrão reconhecido, sendo por vezes desprezada ou então classificada como subliteratura, literatura de mercado, dentre outras terminologias similares, todas apontando para a exclusão, ou ainda, para a "impossibilidade de identificação com estatutos propriamente literários." (BORELLI, 1996 p. 24). A primeira parte desse projeto será dedicada ao aprofundamento da discussão da bibliografia teórica sobre alguns conceitos fundamentais que estão estritamente ligados ao fenômeno do best seller, como: cultura, cultura popular, indústria cultural e cultura de massa. Em seguida realizaremos uma análise literária do primeiro volume da série O Diário da Princesa, à luz de características do realismo formal, conceito formulado pelo crítico lan Watt, buscando identificar os recursos e elementos textuais que fundamentam o pacto ficcional entre o texto e o leitor, a fim de compreender os significados que a obra pode apresentar, entendendo, assim o porquê de ser uma "campeã de vendas".

\section{Resultados e Discussão}

O diário da princesa Mia Thermopolis possui dois aspectos fundamentais que o caracterizam como tal: o pacto de sinceridade estabelecido pelo diarista e a questão temporal. Cabot situa os fatos da narrativa em um esquema temporal bem detalhado. $O$ sobrescrito de cada entrada no diário informa a data e o dia da semana, e em algumas passagens, fornece a hora e o local em que se deu a ação. Essas informações, segundo Watt (2010, p.24) conferem fidelidade do romance à experiência cotidiana, uma vez que tal gênero depende diretamente do emprego de uma escala temporal muito mais minuciosa. Na estrutura narrativa de "O Diário da Princesa" espaço é tão importante quanto o tempo, uma vez que tal dimensão é identificada como uma parte da realidade a ser narrada, influenciando no desenvolvimento das trajetórias individuais. Watt (2010, p. 27) afirma que o espaço é o correlativo do tempo, isto é, "não conseguimos facilmente visualizar um momento particular da existência sem situá-lo também em seu contexto espacial". Dessa forma, se por um lado temos o espaço e o tempo, por outro temos que o diário é um gênero autobiográfico com horizontes muito fluídos e, por este motivo, admite uma ampla variedade temática e estrutural, o que o torna um instrumento produtivo ao serviço da ficção. A estrutura diarística de "O Diário da Princesa" fornece algumas informações que permitem reconhecer, na personagem de Mia Thermopolis, elementos essenciais da afetividade humana com os quais os leitores podem se identificar. Uma das facetas mais tocantes da série "O Diário da Princesa" é, provavelmente, a representação das fases, dramas, dúvidas e descobertas do crescimento.

\section{Conclusões}

O diário de Mia Thermopolis aproxima o leitor de um universo conhecido, isto é, a adolescência, o espaço em branco entre a infância e a idade adulta, uma fase de passagem confusa e transitória comum a todos os indivíduos, bem como os apresenta um outro universo, dessa vez desconhecido, o cotidiano de cidadãos nova iorquinos. No entanto, os leitores aceitam participar do texto, pois os episódios narrados, ainda que muitas vezes improváveis, são verossímeis.

\section{Agradecimentos}

Agradeço a Deus. À minha família pelo amor incondicional. Agradeço ao meu orientador Jefferson Cano, pela paciência em esclarecer minhas dúvidas. Ao SAE/UNICAMP pela confiança e investimento.

BORELLI, Silvia Helena Simões. Ação, suspense, emoção: literatura e cultura de massa no Brasil. São Paulo, SP: EDUC: Estação Liberdade, 1996, p.24.

WATT, Ian. A ascensão do romance. São Paulo: Companhia das Letras, 2010, p.24-27. 